\title{
Learning Device Practicality Based on Guided Discovery Learning
}

\author{
$1^{\text {st }}$ Meisa Kurnia \\ Departement of Mathematics \\ Universitas Negeri Padang \\ Padang, Indonesia \\ meisakurnia9@gmail.com
}

\author{
$2^{\text {nd }}$ Yerizon \\ Departement of Mathematics \\ Universitas Negeri Padang \\ Padang, Indonesia
}

\begin{abstract}
Mathematics learning purposes for student is having the capability or skill to solve a mathematic's problem, as a mean for students to sharpen accuracy, logical, critical, analytical, and creative reasoning so that problem was not a problem anymore for students. For optimal learning process, it is necessary supported by relevant learning device. This is the basis for research in mathematics learning device development like the lesson plan and student worksheet based on guided discovery learning model where learners are also learning and thingking-to solve their problems independently through the materials facilitated by teachers and teacher's guidance. This research was development research which applied PlompModel. Based on the result, it could be concluded that guided discovery learning was practicality.
\end{abstract}

Keywords — guided discovery learning, practicality

\section{INTRODUCTION}

National Mathematics as one of the subjects in school plays an important role because the purpose of learning mathematics is the formation of thinkability of learners. The thinking ability of the learner is reflected through the mathematical abilities that are useful for solving a daily problem both in the field of mathematics and other fields.

Math learning is fun is the desire of each learner so that mathematics is not considered a frightening specter again. The process of learning mathematics facilitates learners to find their own conceptual learning materials with meaning. This can be done by designing an interesting activity and encouraging learners to use their thinking. This teacher can pour in the Learning Implementation Plan (lesson plan). To support the attractiveness of lesson plan can be used instructional media such as student worksheets in accordance with the curriculum used to achieve the expected learning objectives.

Mathematics learning is generally still centered on the teacher so that learners are not optimal in constructing their own knowledge. In teaching teachers tend to present a complete concept. Opportunity learners to find the meaningfulness of learning materials are still considered less.

One of the important mathematical skills to be achieved by learners in learning mathematics is the ability problem-solving. According to Hudojo Solving problems in mathematics includes the process of finding answers to a question that requires procedures or steps that are not routine and contained in a form of text, non-routine puzzles situations in real life. Troubleshooting is the process used to solve a problem. If learners are trained to solve problems, learners will be able to make decisions, because learners have become skilled about how to gather relevant information, analyze information, and realize how it is necessary to re-examine the results that have been obtained.

As an ability, problem solving includes activities such as understanding the problem (identifying known data, identifying the data being asked, identifying the data needed to check the adequacy of data, and constructing mathematical models of problems), choosing strategies and implementing strategies, carrying out calculations and interpreting solutions to initial problem and check the correctness of the solution.

The ability of learners to solve problem-solving is still low. These authors find the field based on observations and interviews conducted in SMPN 24 Padang, seen the results of problem-solving ability test is still low. This data is obtained when the author gives 2 pieces of test questions to 28 students to see the ability of problem-solving mathematical learners. The average score of the obtained classes is 6.96 from the ideal score of 20.00. It can be concluded that in solving the problem-solving problem $65.2 \%$ of the students' answers are not correct and this needs to be addressed.

The ability of problem-solving learners that have not been optimal is caused by several things, such as the lack of maximum learning process in the classroom because the learning is still centered on the teacher so that students are not optimal in constructing their own knowledge.

The results of questionnaires given to learners, it was found that most of the students are still rarely involved in solving problems given by the teacher. Most learners also rarely collect information based on teacher-provided problems. Based on the interview of the writer with the mathematics teacher at SMPN 24 Padang, found the problem that learners still difficulties in understanding the subject matter because the students rarely repeat the lessons that have been learned. According to the teacher in outline the learners have been able to identify the elements that are known and asked but to choose a strategy and perform calculations in answering the problem of students is still much wrong. Another problem that is found is the learning device used by teachers is still not complete. No teachers have their own student worksheet for student use.

In an effort to improve students' problem-solving abilities and overcome the above problems, one of the ways that teachers can use is by developing learning tools based 
on Guided Discovery Learning models. The underlying Guided Discovery Learning is

1. Approach to constructivist learning

Learning is the activity of the teacher facilitating and guiding students to think so that students can develop concepts and understanding of something as a result of the students' active construction through experiences that are appropriate to the real-world situation of students (contextual).

\section{Constructivist Theory by John Dewey}

The view of learning according to constructivist theory is the idea that students must make information their own.

According to this theory, the role of the teacher in learning discovery is to encourage students to have experience and conduct experiments that allow learners to find principles for themselves and the teacher guides students to learn. Learning shows a positive influence on shared variables and effective in improving learning outcomes.

\section{Meaningful learning by Bruner}

According to Bruner the best way of learning for students to understand concepts, propositions or principles in mathematics is to compile their own compilation of representations of the concepts, principles or propositions. this building process is more than learning outcomes because the understanding of the material being studied will be more meaningful if done alone. So that learning models that can develop reasoning and understanding of mathematical problem solving are learning models with discovery. This is because the discovery learning model is a progressive learning model and focuses on the activities of students in learning.

4. Kuhlthau's model of the information discovery process

In this case, the teacher acts as a guide for students in learning and the teacher helps students to acquire the knowledge they are looking for by organizing problems, collecting data, communicating, solving problems, and rearranging data so as to form new concepts. The learning process with guided discovery models focuses on questions that are meaningful and lead to the achievement of learning objectives, in this case, a list of activities that have been prepared.

According to Rosdianwinata (2015) Discovery methods in mathematics learning are responded well and can be used as an effort to change teacher-centered learning to be student-centered. Meanwhile, according to Zulkifli (2012) learning with guided discovery can improve learning activities and students' problem-solving abilities.

Guided Discovery Learning model is a learning model that requires students to organize their own way of learning in finding the concept of a learning material. This is in accordance with the Minister of Education and Culture, the principle of graduate competency standards and the standard of learning content in point one, namely learning that is used "from learners are told to find out students" (Minister of Education and Culture no. 22 of 2016).

In an effort to improve the problem solving skills of learners and overcome the above problems, one way that teachers can use is to develop learning devices based on Guided Discovery Learning model. Guided Discovery
Learning model is a learning model that requires learners to organize their own way of learning in finding the concept of a learning material. This is in accordance with Permendikbud, the principles of the competency standards of graduates and the standard of instruction content on point one is the learning used "from learners are told to learners to find out".

According to Markaban Learning with the discovery is important because learners can actively participate in learning, fostering as well as inculcate inquiry (find-out), support the problem-solving ability of learners, providing a vehicle for interaction between learners and learners with teachers and materials learned can achieve high capability and longer imprint because learners are involved in the learning process. This is reinforced by the statement of Khomsiatun that learning with discovery results last long in the memory of learners because learners are directly involved in the process of knowledge formation through experience that it does. In addition, learners become accustomed to face problems and try to find a solution.

\section{METHOD}

The type of research conducted is research development. Research development aims to produce certain products include the process of testing the validity, practicality, and effectiveness. But that will be discussed at this writing only until the stage of practicality. The development model used in this research is the Plomp model. The Plomp model has three development stages: (1) preliminary research stage; (2) prototyping phase; and (3) assessment phase.

The steps of the learning device development plan above can be detailed as follows:

\section{A. Preliminary Research Stage}

At this stage, identification or analysis of the things required for lesson plan and student worksheet development are based on the Guided Discovery Learning model. The purpose of this stage is to define and define the requirements required in the development of lesson plan and student worksheet. At this stage, there are four main steps:

a. Needs analysis, gathering information about the problems contained in mathematics learning in schools.

b. Curriculum analysis. conducted a review of the curriculum used in SMP Negeri 24 Padang.

c. Concept analysis, conducted activities identify, detail and systematically compile the main materials that will be learned by learners.

Analysis of learners. aims to know the characteristics of learners that include academic ability, learning styles, the

level of development of thinking ability and learning motivation learners especially in learning mathematics.

\section{B. Prototyping phase}

Designing a learning device based on Guided Discovery Learning based mathematics analysis in the introductory phase of analysis. At this stage, the main steps undertaken by researchers are:

a. Designing lesson plan and student worksheet, the result is called prototype 1 . 
b. Self-evaluation is a re-correction by researchers against student worksheet after designed. Then done Expert review, is a correction of student worksheet conducted by some experts who have predetermined experts. Once revised and declared valid, the result is called prototype 2 .

c. One to one evaluation, an evaluation of student worksheet conducted by individuals with different levels of ability. Once revised, the result is called prototype 3 .

Small group evaluation, an evaluation of student worksheet conducted by 6 (six) students with different levels of ability. After the revision, the result is called prototype 4.

\section{Assessment phase}

Phase assessment phase conducted by field test in grade VII SMP Negeri 24 Padang. Field trials are called field test stages. The research data was collected through validation sheet, teacher and student response questionnaire, and observation sheet of lesson plan implementation. Validation of the device is done by three lecturers of Mathematics, one lecturer of Language, and one lecturer of Educational Technology State University of Padang (UNP).

\section{RESULT AND DISCUSSION}

\section{A. Preliminary Research Results}

The steps taken for the development of learning devices based on Guided Discovery Learning model is to analyze the objectives within the boundaries of the subject matter to be developed. The main steps that must be done as follows.

At need analysis stage, the collection of information about the mathematical problems contained in mathematics learning. Activities undertaken are observations of the learning process in the classroom and learning outcomes, as well as interviewing teachers of mathematics. The problem seen is the learning tools used by teachers is still not complete. Teachers have not yet developed their own student worksheet for use by learners. Lesson Plan made by the teacher looks good enough and already refers to the standard learning process, only lesson plan can be developed again in the core activities that are with the steps or learning activities that can lead learners to use the ability to solve mathematical problems in the problem of daily life -day can construct the knowledge it possesses.

The curriculum analysis was conducted by reviewing the 2013 curriculum for the mathematics grade VII of SMP / MTs in the first semester. The results of this analysis are used as the reference in the translation of $\mathrm{KD}$, indicators of competency achievement and the allocation of learning time to achieve the learning objectives.

Concept analysis aims to determine the content and subject matter needed in the development of learning tools. The lesson materials in the first semester are Numbers (Integer and Fractional Numbers), Set, Algebraic Form, and Equations and Linear Inequalities One Variable.

The results of interviews with teachers obtained information that class VII students in SMPN 24 Padang have varying academic abilities, including high ability, moderate and low. In general, students who sit in grade VII have the age of 13-14 years. According to Piaget's cognitive development theory, they are in the formal operational phase with the basic characteristics of its development already capable of thinking abstractly, logically, drawing conclusions, interpreting and developing hypotheses. However, in reality, learners are still not able to construct their own knowledge because learning is still centered on the teacher.

Student questionnaire results indicate that the character of learners prefers learning activities in groups. Based on the questionnaire dominant learners choose the blue color for his favorite color. These colors give a lot of positive influence on the psychological readers. This is in accordance with Eisman's opinion (in Syamsuddin, 2014) which states that the blue color has the meaning of honesty, tranquility, loyalty, dependability, harmony, giving the impression of roomy and sensitive. So blue color is chosen as the dominant color for student worksheet specialized learning device.

\section{B. Results Prototyping Phase (design prototype)}

Phase Prototyping Phase is the design stage of the device. This learning tool is designed based on learning characteristics based on Guided Discovery Learning model in the form of Lesson Plan and student worksheet.

\section{1) Lesson Plan}

Lesson plan was developed with reference to Permendikbud No. 22 years 2016 on Standards The process that addresses the components that must exist in the lesson plan include school identity, subject identity, class/semester, subject matter, time allocation, learning objectives, competency standards or indicators of achievement of competencies, learning materials, methods learning, learning media, learning resources, learning steps and assessment of learning outcomes.

In general, the learning activities consist of three activities, namely preliminary activities, core, and cover. Preliminary activities include the delivery of learning objectives, motivation, and apperception. The core activity is an activity that includes the steps of the guided discovery learning model which includes (1) stimulus (stimulation), (2) problem statement, (3) data collection (4) data processing (data processing), (5) verification (verification), (6) generalization (withdrawal). Meanwhile, covering activities include reflecting on the learning process, as well as the delivery of material for subsequent meetings.

\section{2) Student Worksheet}

Student worksheet is developed by taking into account the criteria of the guided discovery learning model process with the provision of stimuli at the beginning of the learning process and taking into account the skills of learners in solving the problem. The types of writing used in the preparation of student worksheet are Comic Sans MS and Franklin Gothic Heavy. This type of writing is used because it is in accordance with the characteristics of writing favored by learners. The size of the letters used ranges from 12 to 18 . Colors in student worksheet are dominated by blue with a pink combination. 
Presentation on student worksheet contains introduction, table of contents, Core Competence and Basic Competence (KD), competency achievement indicators, student worksheet usage guidelines, learner activities, training questions, and referral lists.

Student worksheet has interesting pictures, according to the problem to be solved. student worksheet begins with the provision of stimulus at the beginning of the learning process and pays attention to the skills of learners in solving problems.

Student worksheet uses a simple and communicative language and in accordance with the level of communication SMP grade VII. Writing and language used in student worksheet in accordance with the Indonesian Spelling General Guidelines (PUEBI). The statements and orders contained in student worksheet are arranged with clear sentences so as to direct learners to gain meaning from the material they are studying. The cover or cover page contains the identity or title of student worksheet based on Guided Discovery Learning. The design result of lesson plan and student worksheet is called prototype I.

\section{a. Prototype 1}

Prototype 1 is a design of learning tools that have been developed in accordance with guided discovery learning model. The self-evaluation is done by looking back at the design result of the device and fixing the obvious errors on the device, such as typing errors, word usage, terms, punctuation, and image placement.

Furthermore, there are several key aspects evaluated, namely: the suitability of lesson plan elements, the suitability of the content/learning materials, the suitability of lesson plan and student worksheet based on guided discovery learning. In general, many errors occur in the use of punctuation and typing errors.

After a self-evaluation revision of the errors is made. Then the revised results are consulted and discussed with experts or experts and validated. This stage is also called Expert Review.

Lesson plan validation is done by four validators consisting of three mathematics educators and one language expert. Prior to being validated, some parts of the lesson plan have improved or revised according to the suggestions of the validator.

Overall lesson plan -based guided discovery learning model has met the valid criteria with the average validity index of 0.92 .

The student worksheet validation is performed by five validators consisting of three lecturers of Mathematics Education to validate aspects of presentation and content aspects, one lecturer of Educational Technology to validate the display aspect and one lecturer Language to validate the language aspect. Prior to being validated some parts of student worksheet have improved or revised based on suggestions from validators.

Based on the validator's suggestion, the student worksheet based on the guided discovery learning model should be in accordance with the Indonesian Spelling (PUEBI). Referring to the suggestions given by the validator, an improvement has been made to the developed student worksheet. Overall the validity value of the presentation aspect and the contents of the designed student worksheet obtained a validity score of 0.94 with valid criteria.

Overall, the average validity of student worksheet based on the guided discovery learning model from the language aspect is 0.83 with valid criteria. As for the display aspect, student worksheet based on guided discovery learning model obtained validity value of 0.67 with valid criteria. This means, student worksheet-based guided discovery learning model can be said to be valid.

\section{b. Prototype 2}

Prototype 2 is a revision based on self-evaluation and validator's suggestion to the learning device developed and valid.

Prototype 2 is tested on a one-to-one evaluation of learning tools that have been developed. In this individual evaluation, the researcher gives lesson plan to one mathematics teacher. Evaluation is done by asking the math teacher to comment on lesson plan while learners give comments to student worksheet which have been designed. student worksheet was given to three high school students, SMP Negeri 24 Padang students with high ability, medium and low. The selection of learners for individual evaluation is done by the teacher based on the sequencing of MID results of the semester I.

All three students are obliged to discuss student worksheet, after which they were asked to comment on student worksheet. Learners are asked to pay attention to whether the use of words/terms is not understood by the learner, the possibility of spelling or typing is still wrong, and the suitability of the image or visual appearance and display attractiveness.

Individual evaluation (one-to-one evaluation) is conducted in 6 meetings. Based on the implementation of the individual evaluation phase, it can be seen that the problems with student worksheet cannot be separated from the orders that exist in the student worksheet. The results are given to student worksheet by students that the abilities possessed by students begin to increase in answering and implementing the commands that exist in student worksheet. Students are also able to complete a problem-solving plan by using the methods that have been learned.

After that, the researchers also conducted interviews with students. Based on interviews with each student, the results were obtained that student worksheet was easy to use but there were some parts that needed improvement. The appearance of student worksheet is interesting because there is a combination of blue and other colors favored by students. Students commented that the student worksheet that was designed was creative. There is enough sufficient time to work on student worksheet, which is still lacking because the questions on student worksheet are rather difficult and many.

Interviews on lesson plan were conducted to the mathematics teacher on the compliance of the lesson plan developed with the characteristics of the learner and the level of convenience and the estimated adequacy of time for the use of the lesson. Based on interviews with teachers, information was obtained that the developed lesson plan was good enough and in accordance with the characteristics of the learners who will use it. It is also estimated that the time adequacy is improved, and the last developed lesson plan is clear enough. 


\section{c. Prototype 3}

Prototype 3 is a revision of a one-to-one evaluation of learning tools that have been developed. Then Prototype 3 is tested on a small group evaluation. Student worksheet is given to six high schools, middle and low-class VIIB students of SMP Negeri 24 Padang. The six students were divided into three groups, each group consisting of two people.

Small group evaluations are held in six meetings. Based on the implementation of the small group evaluation phase it can be seen that the problems in student worksheet cannot be separated from the achievement of indicators of mathematical problem-solving abilities. The results are given to student worksheet by students that the mathematical problem-solving abilities possessed by students also began to increase. This can be seen because students have been able to write down the information about the existing problem. Students also have been able to formulate mathematical problems and solve problems so that they get a solution to the problems given.

After a small group trial is completed, learners are given a questionnaire of practicality to see the learners' responses to learning using student worksheet prototype 3 based on guided discovery learning model. Generally, the results of the questionnaire of practicality filled out by learners in small group trials can be seen in Table 1.

TABLE I. DATA ON PRACTICALITY QUESTIONNAIRE RESULTS BY LEARNERS AFTER SMALL GROUP TRIALS

\begin{tabular}{|l|c|c|}
\hline \multicolumn{1}{|c|}{ Rated aspect } & $\begin{array}{c}\text { value of } \\
\text { practicality }(\boldsymbol{\%})\end{array}$ & Category \\
\hline presentation & 81,66 & very practical \\
\hline use & 86,30 & very practical \\
\hline legibility & 87,5 & very practical \\
\hline time efficiency & 75 & practical \\
\hline overall average & $\mathbf{8 2 , 6 1}$ & very practical \\
\hline
\end{tabular}

Based on Table 1, it is seen that the overall value of practicality percentage is $82.61 \%$ with the very practical category. This means that based on a practical questionnaire filled by learners in small group trials, the learning tools based on guided discovery learning models are considered practical.

\section{3) Results of the Assessment Stage}

After a revision based on individual evaluation and small group evaluation, the next learning device conducted the field trial in other words called field test. A limited trial was conducted in the class VIIA SMPN 24 Padang. Testing of learning devices based on guided discovery learning models in large classes. This is done to obtain information about the implementation of learning by using tools in the form of lesson plan and student worksheet to see the practicality.

In the field test phase students are also required to work on problems that exist in student worksheet in groups. Students have been able to answer problems by implementing problem-solving steps.

In addition to being seen from the results of the students' answers to the implementation of the field test phase, this can also be seen based on the observations assessed by observers that the implementation of learning using student worksheet based on guided discovery learning models went well. This can be seen from the results of teacher interviews, teacher response questionnaires and student questionnaire responses. The data can be described as follows.

The Practical questionnaire is given to students and teachers after participating in all learning using guided discovery learning model-based learning tools. Based on the results of the interview, it can be concluded that the learning device is clear in the use of images and writing, the words used do not create multiple meanings. In addition, in terms of ease of use, teachers are of the opinion that learning tools are easy to use, except that the level of difficulty and number of questions on student worksheet can be simplified. Adequacy of time to use the designed learning device in accordance with the time provided. Thus, it can be concluded that the learning tools developed are practical for use in classroom learning.

The result of student worksheet practice based on guided discovery learning model according to the response of learners can be seen in Table 2 and according to the teacher's response can be seen in Table 3 .

TABLE II. RESULTS OF STUDENT RESPONSE QUESTIONNAIRE TO STUDENT WORKSHEET BASED ON GUIDED DISCOVERY LEARNING MODEL

\begin{tabular}{|l|c|c|}
\hline \multicolumn{1}{|c|}{ Rated aspect } & $\begin{array}{c}\text { value of } \\
\text { practicality }(\boldsymbol{\%})\end{array}$ & Kategori \\
\hline Presentation & 71,10 & practical \\
\hline process of use & 70,20 & practical \\
\hline Legibility & 71,88 & practical \\
\hline time efficiency & 67,97 & practical \\
\hline overall average & $\mathbf{7 0 , 2 9}$ & practical \\
\hline
\end{tabular}

In Table 2, it is seen that the average level of student worksheet practicality based on guided discovery learning model according to the learners' response is $70.29 \%$. Thus, it can be concluded that student worksheet based guided discovery learning model is practical according to the learners' responses.

TABLE III. RESULTS OF TEACHER RESPONSE QUESTIONNAIRE ON STUDENT WORKSHEET MATHEMATICS BASED ON GUIDED DisCOVERY LEARNING MODEL

\begin{tabular}{|l|c|c|}
\hline Rated aspect & $\begin{array}{c}\text { value of } \\
\text { practicality }(\%)\end{array}$ & Category \\
\hline attractiveness & 87,5 & very practical \\
\hline process of use & 100 & very practical \\
\hline legibility & 100 & very practical \\
\hline time efficiency & 75 & Praktis \\
\hline overall average & $\mathbf{9 0 , 6 3}$ & very practical \\
\hline
\end{tabular}

In Table 3, the average value of practicality is $90.63 \%$ with very practical category. This means that based on a practical questionnaire filled by teachers after field trials, the guided discovery learning model-based learning tool is considered practical.

\section{CONCLUSIONS AND RECOMMENDATIONS}

This research is a development research which produce learning device based on guided discovery learning 
model in the form of lesson plan and student worksheet. Based on the research that has been implemented, it is concluded that the learning devices that meet the practical criteria with the characteristics of the existence of ease in the use of student worksheet based guided discovery learning model.

It is recommended for teachers and learners to keep using this student worksheet, in order to help improve students' mathematical problem solving skills and support from the school to facilitate the use of student worksheet required by teachers.

\section{REFERENCES}

[1] Arikunto. Suharsimi, Dasar-Dasar Evaluasi Pendidikan, Jakarta: Bumi Aksara, 2008.

[2] Depdiknas, Panduan Pengembangan Materi Pembelajaran dalam Standar Sarana dan Prasarana Sekolah Menegah Kejuruan Madrasah Aliyah SMA/ MA/ SMK/ MAK, Jakarta: Depdiknas, 2008.

[3] Hudojo. Herman, Pengembangan Kurikulum dan Pembelajaran Matematika. Malang: Penerbit Universitas Negeri Malang, 2005.

[4] Peraturan Menteri Pendidikan Nasional Nomor 22 Tahun 2006 Tentang Standar Isi, Jakarta: Kemendiknas, 2006.

[5] Peraturan Menteri Pendidikan dan Kebudayaan Nomor 58 Tahun 2014 tentang Kurikulum 2013 SMP/MTs, Jakarta: Kemdikbud, 2014.

[6] Peraturan Menteri Pendidikan dan Kebudayaan Nomor 59 tahun 2014 tentang Kurikulum 2013 SMA/MA, Jakarta : Kemdikbud, 2014.

[7] Peraturan Menteri Pendidikan dan Kebudayaan Nomor 103 Tahun 2014 tentang pembelajaran pada pendidikan dasar dan menengah, Jakarta : Kemdikbud, 2014.

[8] Khomsiatun. Siwi dan Heri Retnawati, "Pengembangan Perangkat Pembelajaran dengan Penemuan Terbimbing untuk Meningkatkan Kemampuan Pemecahan Masalah", Jurnal Riset Pendidikan Matematika Volume 2 - Nomor 1, Mei 2015 (92-106). ISSN : 23562684, 2015.

[9] Kurniasih. Imas dan Berlin Sani, "Sukses Mengimplementasikan Kurikulum 2013”, Yogyakarta : Kata Pena, 2014.

[10] Markaban, "Model Penemuan Terbimbing pada Pembelajaran Matematika SMK", Yogyakarta : Pusat Pengembangan dan Pemberdayaan Pendidik dan Tenaga Kependidikan Matematika, 2008.

[11] NCTM, Principles and Standards for School Mathematics, 2000.

[12] Plomp. T and Nieveen. N., An Introduction to Educational Design Research. Enschede: Netherland Institute for Curriculum Development (SLO), 2013.

[13] Polya. George, How to Solve It: A New Aspect of Mathematical Method (Second ed.). Princeton , N.J.: Princeton Science Library Printing, 1973.

[14] Riduwan, Belajar Mudah (Penelitian untuk Guru, Karyawan, dan Peneliti Pemula), Alfabeta: Bandung, 2010.

[15] Rosdianwinata. Eko, "Penerapan Metode Discovery untuk Meningkatkan Kemampuan Pemecahan Masalah Matematika Siswa. Mendidik”, Jurnal Kajian Pendidikan dan Pengajaran, Vol 1 no 1. Hal 1-8, 2015.

[16] Ruseffendi. HET, Pengantar Kepada Membantu Guru Mengembangkan Kompetensinya dalam Pengajaran Matematika untuk Meningkatkan CBSA. Bandung. Tarsito, 2006.

[17] Tessmer. Martin, Planning and Conducting Formative Evaluations, London, , 1993

[18] Walpole. E Ronald, Pengantar Statistika, Jakarta: PT Gramedia Pustaka Utama, 1992.

[19] Zulkifli, "Peningkatan aktifitas dan kemampuan pemecahan masalah matematika melalui Penemuan Terbimbing Siswa Kelas VIII/2 SMPN 2 Kota Sawahlunto", Padang: Tesis Tidak Diterbitkan, 2012. 